\title{
Growth and production of sea urchin Strongylocentrotus droebachiensis in a high-Arctic fjord, and growth along a climatic gradient $\left(64\right.$ to $\left.77^{\circ} \mathrm{N}\right)$
}

\author{
Martin E. Blicher ${ }^{1,2, *}$, Søren Rysgaard ${ }^{1}$, Mikael K. Sejr ${ }^{2}$ \\ ${ }^{1}$ Greenland Institute of Natural Resources, Kivioq 2, Box 570, 3900 Nuuk, Greenland \\ ${ }^{2}$ National Environmental Research Institute, Vejlsøvej 25, 8600 Silkeborg, Denmark
}

\begin{abstract}
Density, growth and production of Strongylocentrotus droebachiensis were investigated in the outer parts of a high-Arctic fjord $\left(74^{\circ} 18^{\prime} \mathrm{N}, 20^{\circ} 15^{\prime} \mathrm{W}\right)$ in Northeast Greenland based on a combination of high resolution underwater photographs of the sea floor, dredge collections, and age determinations. The average density of 1.8 ind. $\mathrm{m}^{-2}$ (ranging from 0 to 16) from 10 to $60 \mathrm{~m}$ water depth was correlated with depth and amount of rocky substrate. The size structure of $S$. droebachiensis in summer 2004 was unimodal with highest frequencies of individuals between 20 and $50 \mathrm{~mm}$ in diameter. Age estimated from growth increments in the interambulacral and genital plates revealed that growth was slow and that life span reached $45 \mathrm{yr}$. Annual production was estimated at $0.307 \mathrm{~g}$ ash-free dry weight (AFDW) $\mathrm{m}^{-2}$, of which gonad production made up $\sim 67 \%$, thereby greatly influencing the production-to-biomass ratio of 0.29 . The annual carbon demand of $S$. droebachiensis was estimated at $\sim 37 \mathrm{t} \mathrm{C}$ in the outer part of the fjord $\left(76 \mathrm{~km}^{2}\right.$; average $\left.=0.49 \mathrm{~g} \mathrm{C} \mathrm{m}^{-2}\right)$, corresponding to $3.5 \%$ of the total benthic and pelagic primary production, or $2.9 \%$ of the sedimentation of organic carbon within this area. Collections of $S$. droebachiensis from 7 populations from sub- to high-Arctic areas revealed a decline in growth performance along a south-north climate gradient in Greenland $\left(64\right.$ to $\left.77^{\circ} \mathrm{N}\right)$. Difference in length of the productive open-water period explained more than $80 \%$ of the variability in growth $(p<0.01)$ between populations and these findings are discussed in relation to predictions of future reductions in Arctic sea ice cover.
\end{abstract}

KEY WORDS: Macrobenthos · Population dynamics $\cdot$ Carbon demand $\cdot$ Climate impacts

\section{INTRODUCTION}

The Arctic, and especially coastal Greenland, has traditionally been given little attention in marine ecological studies, and many aspects of ecosystem structure, production and carbon-flow pathways in this remote area remain unknown. Reports of high standing stocks of macrobenthos in some Arctic areas have led to suggestions that benthic-pelagic coupling is particularly strong in polar areas, indicating that the benthos plays a key ecological role in the marine ecosystem (e.g. Petersen \& Curtis 1980). Although Piepenburg (2005) proposed that this conclusion might be too general, there is strong evidence that benthic communities are highly influenced by physical as well as biological processes in the overlying water column It is clear that detailed knowledge about Arctic benthos is lacking and that more extensive studies of population dynamics are necessary to further elucidate the ecological role of benthic fauna relative to other biological communities in Arctic marine ecosystems. The potential impact of a warming climate emphasises the urgent need for such studies. The Arctic has been widely accepted as an environment vulnerable to accelerating climatic change and it is predicted that the effects of future global warming will be amplified in this area (e.g. Serreze et al. 2000). Impacts on sea ice thickness and seasonal distribution of ice in the Arctic are well documented (Serreze et al. 2000, Johannesen et al. 2002) and atmosphere-ocean general circulation 
models predict an ice-free Arctic Ocean in the summer period by the end of this century (Johannesen et al. 2002, Arzel et al. 2006). It is unclear to what extent and at which level marine ecosystems will be affected by these changes, but significant ecological effects are expected (Johannesen et al. 2002, Piepenburg 2005). Rysgaard et al. (1999) predicted an increase in annual primary production in the Arctic as a consequence of a prolonged ice-free period. This could alter food conditions for the benthos and change the rates of benthic secondary production in Arctic ecosystems. Comparison of biological variables and structures along existing climate gradients might contribute to our understanding of the influence of climate on the marine ecosystem and help us predict the scale of potential ecological impacts of global warming.

To obtain detailed knowledge of the ecological role of a benthic species in an Arctic fjord, and in an attempt to predict possible changes in benthic production in Arctic areas expected to undergo marked climate changes in future decades, this study aimed to (1) describe density, growth and production of the regular sea urchin Strongylocentrotus droebachiensis (O. F. Müller, 1776) living in a high-Arctic environment (Young Sound, Northeast Greenland), and quantify the carbon demand of this species in comparison to primary production, vertical carbon transport and to the carbon demand of other benthic organisms; and (2) compare growth patterns and individual production of S. droebachiensis populations along a climatic gradient in Greenland.

Strongylocentrotus droebachiensis was chosen because it has a circumpolar distribution and has been identified as a dominant species in Arctic habitats (Hop et al. 2002). The species is subject to commercial utilisation, particularly in North America, and most studies on this species have been conducted in relation to fisheries and aquaculture, and to its role as a structuring herbivore in certain habitats (e.g. Himmelman et al. 1983, Chen et al. 2003, Gagnon et al. 2004, Pearce et al. 2004). S. droebachiensis has been observed at numerous localities around Greenland, but data on its ecological role in the Arctic are scarce.

\section{MATERIALS AND METHODS}

A study on the population production and carbon demand of Strongylocentrotus droebachiensis was conducted in the outer part of Young Sound (Fig. 1Region 1 in Rysgaard et al. 2003) in Northeast Greenland $\left(74^{\circ} 18^{\prime} \mathrm{N}, 20^{\circ} 15^{\prime} \mathrm{W}\right.$ ) in August 2004.

Sea urchin density. A series of high-resolution digital photos of the sea floor were taken along 3 transects (H1, H2 and H3) in Young Sound at 10, 20, 30, 40, 50

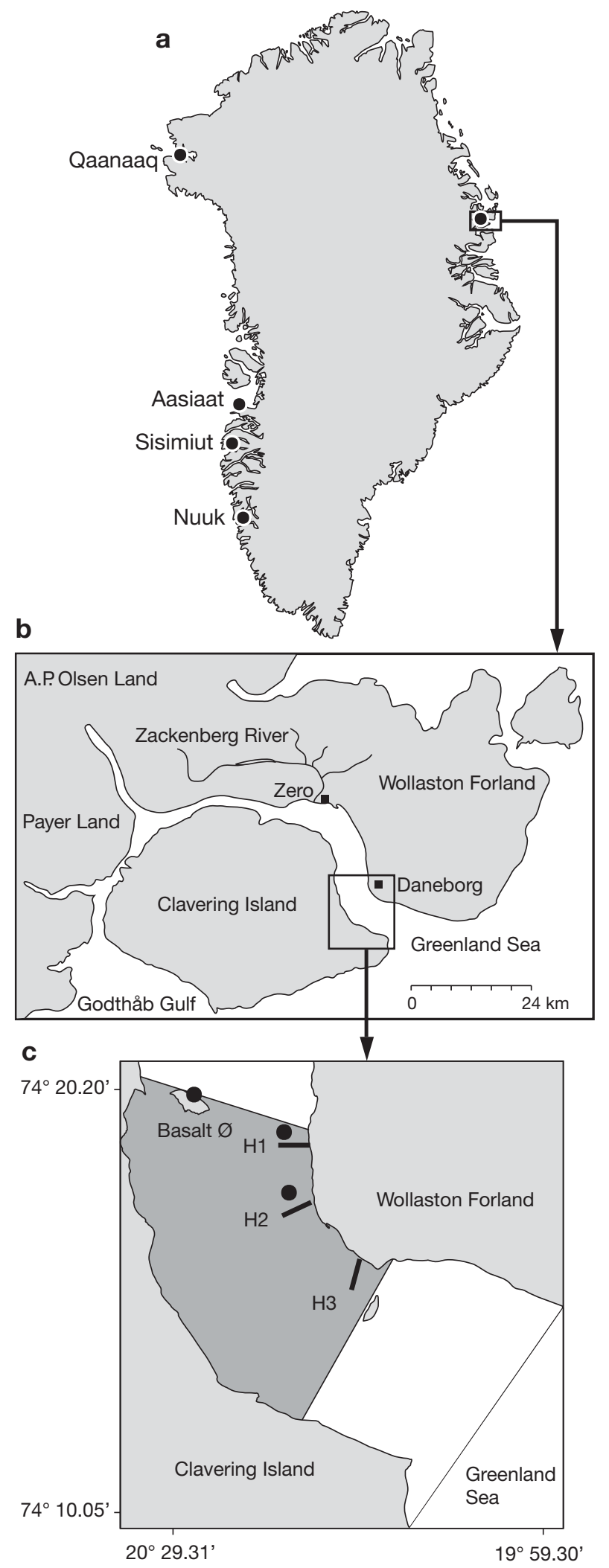

Fig. 1 (a) Locations of sea urchin collection in Greenland $(\bullet)_{i}$ (b) Young Sound, NE Greenland; (c) sampling stations (๑) and Photo Transects H1-H3 (-) in outer Young Sound, with Region 1 indicated by darker shading 
and $60 \mathrm{~m}$ depth and off the island Basalt $\varnothing$ at 15 to $25 \mathrm{~m}$ depth (Fig. $1 \mathrm{c}_{i}$ see also Fig. 2a). Lasers were attached to the system to scale the images. A total of 205 photographs, each covering approximately 0.4 to $0.6 \mathrm{~m}^{2}\left(\sim 101 \mathrm{~m}^{2}\right.$ in total), were used for density estimation of Strongylocentrotus droebachiensis, making it possible to evaluate the influence of depth and substrate type on the density of this species. The area of hard substrate relative to soft bottom was calculated using the image processing software ImageJ $1.3 .5 \mathrm{~s}$. Multiple regression was used to examine the relationship between the dependent variable sea urchin density and the independent variables depth and substrate type (\% cover of rock), and transect as control variable (dummy). The multiple-regression model was estimated by ordinary least squares (OLS). Due to their exogenic character all the regressors are considered uncorrelated with the error term, which implies that the OLS estimates are asymptotically consistent.

Collection and processing. Strongylocentrotus droebachiensis were collected using a triangular dredge (mesh size $0.5 \times 1 \mathrm{~cm}$ ) at a depth of 30 to $40 \mathrm{~m}$ at 2 sites in Young Sound. In addition (because of a steep slope, which made it difficult to use the dredge), SCUBA divers collected specimens off the island Basalt $\varnothing$ at 15 to $25 \mathrm{~m}$ depth (Fig. 1c). Specimens were frozen $\left(-18^{\circ} \mathrm{C}\right)$ immediately after collection and kept frozen until analysis. Maximum diameter and height of each specimen was measured to the nearest $0.1 \mathrm{~mm}$ using vernier callipers and wet weight was determined to the nearest $0.01 \mathrm{~g}$. Some specimens were used for biomass analysis and others for age analysis. The former were carefully dissected into gonads, intestine and somatic tissue. Gonads were weighed to calculate a gonad index (GI):

$$
\mathrm{GI}=\frac{\text { gonad wet weight }(\mathrm{g})}{\text { total wet body weight }(\mathrm{g})}
$$

An equivalent intestinal index was also calculated. Gonad, intestinal and somatic ash-free dry weights (AFDW) were determined by drying at $60^{\circ} \mathrm{C}$ for $24 \mathrm{~h}$ followed by ignition at $550^{\circ} \mathrm{C}$ in a muffle furnace for $12 \mathrm{~h}$. Scaling gonad mass, $M_{g}(\mathrm{~g}$ AFDW) with diameter, $D_{t}(\mathrm{~mm})$, was done by Model II non-linear regression as described in Ebert \& Russell (1994), using the general allometry equation:

$$
M_{g}(D t)=\alpha\left(D_{t}-\gamma\right)^{\beta}
$$

where $\alpha, \beta$, and $\gamma$ are coefficients in the regression. This allows asynchronous development of gonads relative to size.

Age determination. Age determination was carried out using a combination of the methods described by Jensen (1969), Pearse \& Pearse (1975) and Brey (1991). Individuals were carefully cut along the ambitus with a scalpel. Intestine, gonads and Aristotle's lantern were removed. The echinoid skeleton was bleached in a $5 \%$ sodium hypochlorite $(\mathrm{NaOCl})$ solution for 5 to $10 \mathrm{~min}$ to remove organic tissue. The skeleton was dried at $60^{\circ} \mathrm{C}$ for $12 \mathrm{~h}$ and charred in a muffle furnace at $300^{\circ} \mathrm{C}$ for 5 to $10 \mathrm{~min}$. Ossicles were carefully polished with sandpaper (800 grit) on the outside of the plates after which they were placed in xylene. In this way, growth zones in the skeletal plates, consisting of alternating translucent winter zones and opaque summer growth zones, were made visible. To ensure a precise estimate of age when counting the annually formed growth lines in skeletal plates, it is crucial to examine the plates formed at settlement, for instance genital plates. In each row of interambulacral plates, only the 7 plates closest to the mouth contain the first year's growth zone in Strongylocentrotus droebachiensis (Jensen 1969). Plates closer to the aboral side are formed later, as individuals grow. Younger interambulacral plates were, however, often used as a supplement in the process of age determination, since when an individual reaches a certain size, growth of the oldest plates becomes minimal, making the most recent growth zones difficult to differentiate. Recognising corresponding zones in younger plates made it possible to determine age even when growth of the oldest plates was close to zero.

Growth patterns. In an analysis of growth patterns the population of Strongylocentrotus droebachiensis from Young Sound was evaluated together with those of 6 other populations from Greenland (Table 1). This analysis was based on a maximum likelihood estimation (Berry \& Lindgren 1996). An initial model proposed that growth would follow a sigmoidal growth curve of the Richards' family (Richards 1959, Sugden et al. 1981):

$$
D_{t}\left(D_{\infty}, m_{,} t_{*} T\right)=D_{\infty}\left[1-(1-m) \exp \left\{\frac{-t\left(t-t_{*}\right)}{T m^{m /(1-m)}}\right\}\right]^{1 /(1-m)}
$$

where $D_{\infty}$ is the asymptotic diameter $(\mathrm{mm}), t$ is individual age (yr), $t_{*}$ is an age-at-growth inflexion, $T$ (yr) is the time needed to grow from zero to $D_{\infty}$ at maximum growth rate, and $m$ is a shape factor for Richards' curves. $m \rightarrow 0$ corresponds to von Bertalanffy growth, $m \rightarrow 1$ to Gompertz growth, and $m=2$ to single logistic growth. An error term was considered, such that

$$
D_{t}=D_{t}\left(D_{\infty}, m, t_{*}, T\right)+\varepsilon_{t}
$$

where $D_{t}$ is the actual diameter. $\varepsilon_{t}$ is assumed to be normally distributed, with zero mean and a power relationship between its variance and the predicted diameter, $D_{t}\left(D_{\infty}, m, t_{*}, T\right)$ :

$$
\varepsilon_{t} \sim N\left\{0,\left[a D t\left(D_{\infty}, m, t_{*}, T\right)^{b}\right]^{2}\right\}
$$

where $a$ and $b$ define the variance. This is a flexible expression of variance, which implies potential hetero- 
Table 1. Position, depth and time of collection at 7 localities in Greenland

\begin{tabular}{|lccc|}
\hline Locality & Position & Depth (m) & Collection date \\
\hline Young & $74^{\circ} 18^{\prime} \mathrm{N}, 20^{\circ} 15^{\prime} \mathrm{W}$ & $15-40$ & Mid-Aug. 2004 \\
Sound & & & \\
Qaanaaq & $77^{\circ} 26^{\prime} \mathrm{N}, 69^{\circ} 14^{\prime} \mathrm{W}$ & $15-20$ & Mid-Oct. 2005 \\
Aasiaat & $68^{\circ} 43^{\prime} \mathrm{N}, 52^{\circ} 38^{\prime} \mathrm{W}$ & $33-40$ & Mid-Aug. 2004 \\
Sisimiut & $67^{\circ} 04^{\prime} \mathrm{N}, 53^{\circ} 59^{\prime} \mathrm{W}$ & $30-40$ & Mid-Oct. 2005 \\
Nuuk 1 & $64^{\circ} 00^{\prime} \mathrm{N}, 51^{\circ} 42^{\prime} \mathrm{W}$ & $30-40$ & Late-Sep. 2005 \\
Nuuk 2 & $64^{\circ} 05^{\prime} \mathrm{N}, 51^{\circ} 48^{\prime} \mathrm{W}$ & $30-40$ & Late-Sep. 2005 \\
Nuuk 3 & $64^{\circ} 08^{\prime} \mathrm{N}, 51^{\circ} 39^{\prime} \mathrm{W}$ & $5-15$ & Mid-Aug. 2005 \\
\hline
\end{tabular}

scedasticity. However, the expression contains, and can easily be collapsed to, the common simple forms, e.g. $b=0$ gives homoscedastic errors, $b=1$ gives standard deviation proportional to diameter. Parameters were fitted by maximising the joint likelihood of the $\varepsilon_{t}$ values, $\ln (\mathrm{L})$. The characteristics of the parameter $D_{0}$, diameter at zero age, were also examined. An initial model fitted values of all 6 parameters to each of the 7 groups, and the model was reduced by constraining parameter values for different groups to be equal or to have specific values. Constraints were tested by likelihood-ratio tests, where the value $-2 \ln \left(\mathrm{L}_{0} / \mathrm{L}_{1}\right)$ was tested as $\chi^{2}$ with degrees of freedom equal to the number of constraints. Akaike's information criterion (AIC) $=-2 \ln (\mathrm{L})+2 K$ (where $K$ is the number of parameters in the model) was also referred to in respect of choosing one model over another (Lebreton et al. 1992).

Production calculations. Annual somatic production of an average individual, $P_{S(\text { ind }) \text {, }}$ in the population was estimated using the mass specific growth rate method (Brey 2001), which incorporates (1) size frequency pooled over stations, (2) growth function and (3) the size-mass relationship

$$
P_{S(\text { ind })}=\sum_{i} F_{i} M_{s, i} G_{i}
$$

where $F_{i}$ is the frequency of Size Class $i$ (2 mm intervals) in the population, $M_{s, i}$ is the somatic mass ( $g$ AFDW) of an average individual in Size Class $i$, and $G_{i}$ is the weight-specific growth rate $\left(\mathrm{yr}^{-1}\right)$ of an average individual in Size Class $i$. Specifically:

$$
G_{i}=-\frac{b\left[D_{t}-D_{t}^{m} D_{\infty}^{(1-m)}\right]}{D_{i}(1-m) T m^{m /(1-m)}}
$$

where $b$ is the exponent of the size-mass relationship. $T, m, D_{t}$ and $D_{\infty}$ are parameters from the growth model (Eq. 3), and $D_{i}$ is the mean diameter of Size Class $i$.

Annual gonad production of an average individual in the population, $P_{g(\text { ind })}$, was estimated from the regression of individual gonad mass on diameter, and the pooled size frequency distribution. Based on Brey et al. (1995), Meidel \& Scheibling (1998a) and Oganesyan
(1998), gonad output was set at $60 \%$ of individual prespawning gonad mass:

$$
P_{g \text { (ind) }}=\sum_{i} F_{i} M_{g, i} \times 0.6
$$

where $M_{g, i}$ is the gonad mass of an average individual in Size Class $i$, estimated from the gonad mass vs. diameter regression.

Total annual production of Strongylocentrotus droebachiensis in outer Young Sound was calculated from Eq. (6), Eq. (8) and sea urchin densities. Average production $\left(\mathrm{m}^{-2}\right)$ at each depth was multiplied by the area of the relevant depth intervals in the outer part of the fjord (Region 1) calculated by Rysgaard et al. (2003). Production estimated at $10 \mathrm{~m}$ depth was considered representative of the 5 to $15 \mathrm{~m}$ depth interval, $20 \mathrm{~m}$ was representative of 15 to $25 \mathrm{~m}$, and so forth. As the island Basalt $\varnothing$ was not considered in the area estimate of Rysgaard et al. (2003), based on GPS positions along the coast of Basalt $\varnothing$ and along the $30 \mathrm{~m}$ depth curve off the island, we used the software Ozieexplorer Version 3.95 to calculate the area of the sea floor in the 0 to $30 \mathrm{~m}$ depth interval around the island.

Carbon content estimation. Organic carbon contents of somatic and gonad tissue were determined on 11 replicate individuals. Samples were dried, homogenised and treated with $\mathrm{H}_{2} \mathrm{SO}_{3}$ (somatic) to remove skeletal carbonate, and analysed on a $\mathrm{C} / \mathrm{N}$ elemental analyser (RoboPrep-C/N, Europa Scientific).

Growth and climate. In order to investigate growth patterns along a climatic gradient in Greenland, Strongylocentrotus droebachiensis were also collected off Qaanaaq $\left(77^{\circ} \mathrm{N}\right)$, Aasiaat $\left(68^{\circ} \mathrm{N}\right)$, Sisimiut $\left(67^{\circ} \mathrm{N}\right)$, and at 3 stations off Nuuk $\left(64^{\circ} \mathrm{N}\right)$ in West Greenland in shallow water $(<40 \mathrm{~m})$ (Fig.1a, Table 1$)$. Daily estimates of sea ice cover for each site were extracted from satellite data (Gloerson et al. 1990, Maslanik \& Stroeve 2004) between 1978 and 2004. The data were used to estimate 'productive open-water periods' for the areas of sea urchin collection. These were defined as the annual number of days with open water and day lengths of at least $6 \mathrm{~h}$, below which primary production was expected to be near zero due to light limitation (Smidt 1979, S. Rysgaard unpubl.).

\section{RESULTS}

\section{Young Sound}

\section{Distribution and size structure}

Photographs of the sea floor along Transects H1, H2 and H3, and off Basalt $\varnothing$ in outer Young Sound showed an average density of 1.81 ind. $\mathrm{m}^{-2}(\mathrm{n}=190, \mathrm{SE}=$ 0.0191, ranging from 0 to 16 ind. $\mathrm{m}^{-2}$ ) (Fig. 2a,b). Depth 

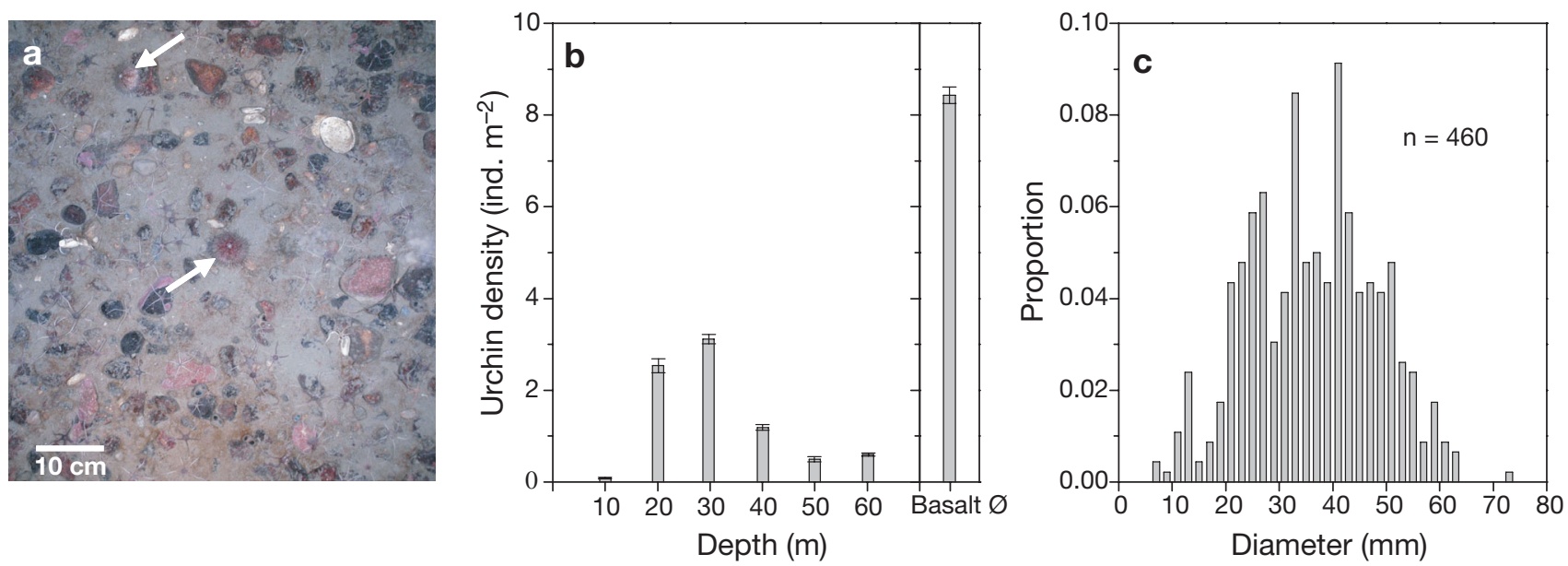

Fig. 2. Strongylocentrotus droebachiensis. Density and size structure in Young Sound. (a) Digital photograph of sea floor at $40 \mathrm{~m}$ depth, with sea urchins indicated by arrows; (b) sea urchin density at 10 to $60 \mathrm{~m}$ depth (mean \pm SE, $\mathrm{n}=30$ at each depth), and off Basalt $\varnothing(\mathrm{n}=25)$; (c) Size frequency distribution ( $2 \mathrm{~mm}$ size classes) pooled over stations

and the amount of hard substrate explained a statistically significant fraction of the variation in sea urchin density $\left(\mathrm{R}^{2}=0.54\right)$. Rocky substrate was found to have a strong and statistically significant $(p<0.01)$ positive effect on density. The direct effect of depth was not statistically significant, but depth had an indirect effect on density due to the statistically significant interaction term. This means that increasing depth resulted in a decline in the positive effect of rocky substrate (Table 2, Model I). To examine the robustness of the results to the fact that data were sampled at 4 different places in Young Sound, dummy variables were added to the model. This affected neither the size nor the statistical significance of the coefficients from the previous model. A difference between transects was found only between H1 and H3 ( $p<0.05)$.

Table 2. Strongylocentrotus droebachiensis. Multiple regression models for effect of depth and substrate on sea urchin density (ind. $\mathrm{m}^{-2}$ ) in Young Sound. SEs are heteroscedasticityconsistent; control variables: only significant difference between H1 and H3 $(\mathrm{p}<0.05) .{ }^{*} \mathrm{p}<0.05 ;{ }^{* *} \mathrm{p}<0.01$

\begin{tabular}{|lcc|}
\hline & $\begin{array}{c}\text { Model I } \\
\text { Coefficients (SE) }\end{array}$ & $\begin{array}{c}\text { Model II } \\
\text { Coefficients (SE) }\end{array}$ \\
\hline Intercept & $0.679(0.367)$ & - \\
Substrate (\% rock) & $0.246^{* *}(0.045)$ & $0.276^{* *}(0.088)$ \\
Depth (m) & $-0.004(0.007)$ & $0.0002(0.008)$ \\
Depth $\times$ Substrate & $-0.004^{* *}(0.001)$ & $-0.006^{*}(0.002)$ \\
Control variables & & \\
H1 $(\mathrm{n}=60)$ & - & $1.494^{*}(0.649)$ \\
H2 $(\mathrm{n}=60)$ & - & $0.512(0.351)$ \\
H3 $(\mathrm{n}=60)$ & - & $0.114(0.282)$ \\
Basalt $\varnothing(\mathrm{n}=10)$ & - & $0.108(3.149)$ \\
$\mathrm{R}^{2}$ & 0.540 & 0.563 \\
\hline
\end{tabular}

The small island Basalt $\varnothing$, which is surrounded by a steep slope and dominated by rocky ground, had statistically significantly higher sea urchin density at 15 to $25 \mathrm{~m}(\mathrm{n}=25)$ than the $20 \mathrm{~m}$ sites on Transects $\mathrm{H} 1-\mathrm{H} 3$ (n = 30) $(U=111 ; \mathrm{p}<0.01$, Mann-Whitney $U$-test).

The maximum study depth was limited by the underwater camera equipment, resulting in a lack of data below $60 \mathrm{~m}$. However, dredge collections at depths down to $100 \mathrm{~m}$ revealed that the abundance of Strongylocentrotus droebachiensis was extremely low at these depths. The pooled size distribution showed an approximately unimodal pattern dominated by individuals between 20 and $50 \mathrm{~mm}$ (Fig. 2c). The absence of small urchins was also noted during dives and is thus presumably not a result of ineffective sampling of the smallest size groups.

\section{Age}

The skeletal growth zones in Strongylocentrotus droebachiensis were very distinct. In each specimen it was possible to identify growth zones of 1 or several specific years in different plates by recognisable characteristics of the zones (Fig. 3), enabling the younger, faster-growing interambulacral plates to be included in age determination. The estimate of age based on genital plates was usually equal to, or at least very close to, the estimate based on counts of interambulacral plates ( \pm 1 to $2 \mathrm{yr}$ ). Where differences occurred, the average of the 2 methods was used for the sizeat-age plot. In a few cases $(<5 \%)$, however, reduced growth of genital plates of the oldest individuals made it impossible to determine age with sufficient accuracy, and estimates were not made. 

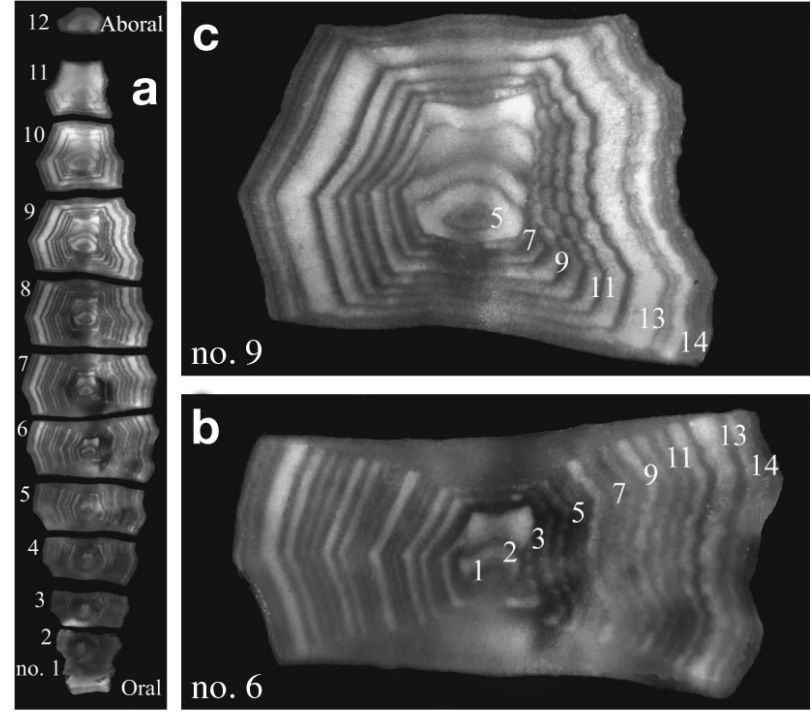

Fig. 3. Strongylocentrotus droebachiensis. (a) Row of interambulacral plates from oral to aboral side of a specimen (diameter $34.6 \mathrm{~mm}$ ) showing annual growth bands, age estimated at $14 \mathrm{yr}_{;}$(b) interambulacral plate containing all growth zones; (c) younger plate containing only latest 10 growth zones. Panels $(b, c)$ : Nos. on every 2 nd line indicate the age $(\mathrm{yr})$ at which it was created

\section{Growth patterns}

The growth function (Eq. 3) was fitted to size-at-age data for specimens $(n=112)$ from 3 sites in outer Young Sound (Fig. 4):

$$
\hat{D}_{\mathrm{t}}=64.35\{1+0.975 \exp [-0.185(t-10.989)]\}^{-1.025}
$$

which corresponds to $T=21.420, m=1.975, t_{*}=10.989$, and $D_{\infty}=64.35$ in Eq. (3) (see later subsection for statistics). The Richards' function fitted the data set

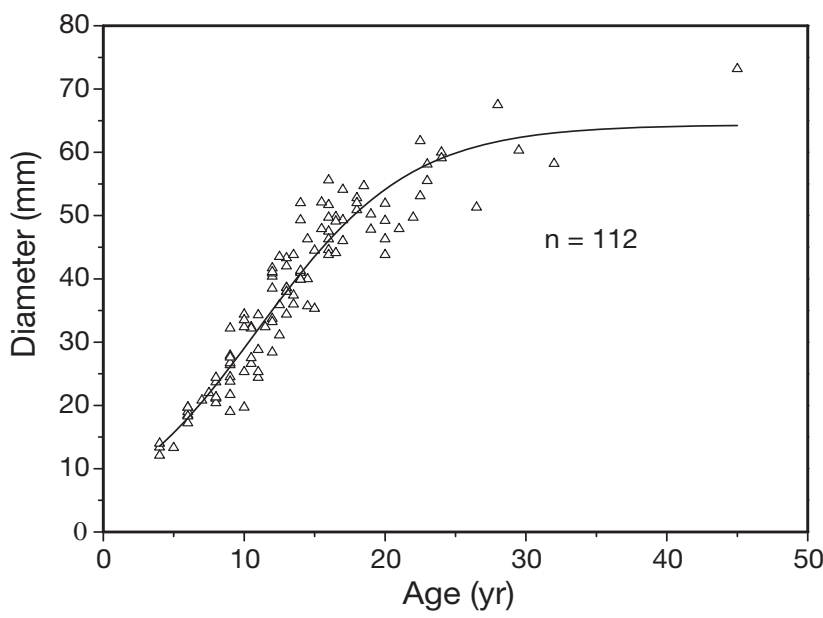

Fig 4. Strongylocentrotus droebachiensis. Growth function fitted to diameter-at-age data for sea urchins from Young Sound. Age estimated from growth bands in skeletal plates slightly better than the Tanaka function, which has been applied to sea urchins in other studies (Russell et al. 1998, Ebert et al. 1999). The oldest specimen had an estimated age of $45 \mathrm{yr}$ (73.2 $\mathrm{mm})$.

\section{Individual biomass and production}

The relationship ( $\mathrm{n}=33 ; D_{t}$ from 11.6 to $63.4 \mathrm{~mm}$; $\left.\mathrm{R}^{2}=0.99\right)$ between somatic mass, $M_{s}(\mathrm{~g}$ AFDW), and test diameter, $D_{t}(\mathrm{~mm})$ was

$$
M_{S}=4.8 \times 10^{-5} \times D_{t}^{2.5219}
$$

Strongylocentrotus droebachiensis has a well defined spawning event once each year in the spring/early summer (Meidel \& Scheibling 1998a, Oganesyan 1998). Thorson (1936) observed larvae in the water column in June, July and August in NE Greenland, with a pronounced maximum in June. This corresponds well with the assumption that most individuals from Young Sound were in post-spawning state at the time of collection (gonad index $=0.0341, \mathrm{n}=43, \mathrm{SE}=0.0009$ ). For estimation of annual production, 3 scenarios for the relationship between gonad mass $\left(M_{g}\right)$, and diameter were considered: (1) regression using all observations of gonad mass vs. urchin diameter; (2) regression for the largest observations (GI > 0.05); (3) regression using values of gonad mass corresponding to a gonad index of 0.15 (based on total wet body weight), which is a common pre-spawning value for this species (Meidel \& Scheibling 1998a, Oganesyan 1998) (Table 3 \& Fig. 5a). (1) and (3) were expected to represent a minimum and maximum estimate, respectively, of gonad mass for the Young Sound population. The latter corresponded well to the $M_{g}$ vs. size relationship of this study's northernmost population off Qaanaaq collected more than 2 mo later during the process of gonad build-up $\left(M_{g}=\right.$ $\left.1.042 \times 10^{-8}\left(D_{t}-3.830\right)^{4.510} ; \mathrm{n}=42\right)$. Thus, (2) was considered to provide a reasonable, although conservative,

Table 3. Strongylocentrotus droebachiensis in Young Sound. Parameters and SEs of general allometry equation for gonad mass $M_{g}$ (g AFDW) as function of diameter $D_{t}: M_{g}\left(D_{t}\right)=$ $\alpha\left(D_{t}-\gamma\right)^{\beta}$ following 3 scenarios: (1) Regression for all observations of gonad mass vs. size; (2) regression for largest observations (gonad index, GI > 0.05); (3) regression using values of gonad mass corresponding to GI of 0.15 (see Fig. 5)

\begin{tabular}{|ccccc|}
\hline & $\mathrm{n}$ & $\alpha$ & $\beta$ & $\gamma$ \\
\hline 1 & 83 & $2.370 \times 10^{-7}$ & 3.637 & 5.136 \\
& & $\left(9.68 \times 10^{-8}\right)$ & $(0.113)$ & $(0.780)$ \\
2 & 13 & $3.724 \times 10^{-4}$ & 1.900 & 8.600 \\
& & $\left(2.601 \times 10^{-4}\right)$ & $(0.177)$ & $(1.042)$ \\
3 & 73 & $1.235 \times 10^{-5}$ & 2.816 & 0.819 \\
& & $\left(3.82 \times 10^{-6}\right)$ & $(0.080)$ & $(0.067)$ \\
\hline
\end{tabular}



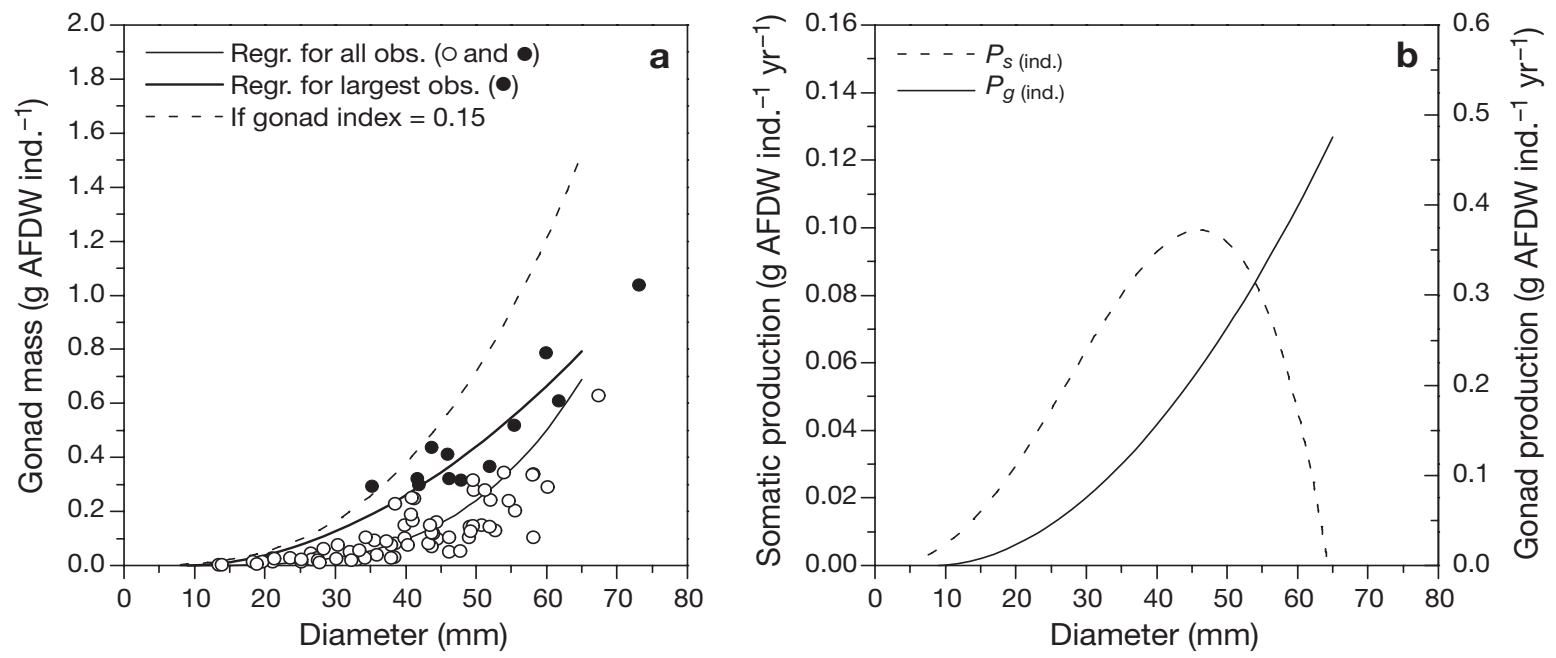

Fig. 5. Strongylocentrotus droebachiensis. Individual production in Young Sound. (a) Gonad mass vs. diameter following 3 scenarios (Table 3$) ;\left(\right.$ b) annual somatic $\left(P_{s(\text { ind.) }}\right)$ and gonad $\left(P_{g(\text { ind.) }}\right)$ production vs. diameter

estimate of the relationship between gonad mass and diameter in a pre-spawning situation in Young Sound. Assumption of an annual gonad output of $60 \%$ (Brey et al. 1995, Meidel \& Scheibling 1998a, Oganesyan 1998) of pre-spawning gonad mass resulted in the gonad production vs. diameter relation illustrated in Fig. 5b. Annual somatic production reaches a maximum of $0.099 \mathrm{~g}$ AFDW ind. ${ }^{-1}$ at a diameter of $\sim 45 \mathrm{~mm}$, after which it declines. If the size frequencies in Fig. 2c are considered representative of the population, the average somatic production would be $0.071 \mathrm{~g}$ AFDW ind. ${ }^{-1} \mathrm{yr}^{-1}$. The minimum and maximum estimates of the average individual gonad production would be 0.067 and $0.222 \mathrm{~g} \mathrm{AFDW}$ ind..$^{-1} \mathrm{yr}^{-1}$, respectively, indicating that gonads make up 49 to $76 \%$ of the total annual production (considering Regressions 1 to 3). If Regression 2 is considered to provide the best estimate of gonad mass vs. diameter in a pre-spawning situation, the total somatic and gonad production would amount to $0.214 \mathrm{~g}$ AFDW ind. ${ }^{-1} \mathrm{yr}^{-1}$.

\section{Population biomass and production}

Sea urchin densities estimated from Photo Transects $\mathrm{H} 1, \mathrm{H} 2$ and $\mathrm{H} 3$ were considered as representative of Region 1 as a whole, while the Basalt $\varnothing$ transect was treated separately. The high density of Strongylocentrotus droebachiensis off Basalt $\varnothing$ was considered a local phenomenon caused by the steep and rocky slope around the island. Divers could not recognise any obvious changes in $S$. droebachiensis density or in the habitat during dives down to $30 \mathrm{~m}$ depth off Basalt $\varnothing$. Density estimated from the photographs (at 15 to $25 \mathrm{~m}$ depth) was therefore extrapolated to this depth interval.

Table 4 summarises the calculation of Strongylocentrotus droebachiensis production for Region 1 in Young Sound. Density was highest at depths of 20 to $40 \mathrm{~m}$, where the total production was estimated at 0.25 to $0.67 \mathrm{~g} \mathrm{AFDW} \mathrm{m}^{-2} \mathrm{yr}^{-1}$. Off Basalt $\varnothing$, production was as high as $1.81 \mathrm{~g} \mathrm{AFDW} \mathrm{m}^{-2} \mathrm{yr}^{-1}$. On average, this value is

Table 4. Strongylocentrotus droebachiensis. Mean (SE) somatic $\left(P_{s}\right)$ and gonad $\left(P_{g}\right)$ production at population level in Young Sound $($ Region 1 in Fig. 1). $P_{s \text { (pop) }}$ and $P_{g \text { (pop): }}$ area-specific production; $P_{s(\text { tot })}$ and $P_{g \text { (tot) }}$ : population production at given depth intervals. Total production estimated at $7.4 \mathrm{t} \mathrm{AFDW} \mathrm{yr}^{-1}$

\begin{tabular}{|c|c|c|c|c|c|c|c|}
\hline $\begin{array}{l}\text { Depth } \\
\text { (m) }\end{array}$ & Ind. $\mathrm{m}^{-2}(\mathrm{SE})$ & $\begin{array}{l}\text { Biomass (SE) } \\
\left(\mathrm{g} \text { AFDW m }{ }^{-2}\right)\end{array}$ & $\begin{array}{c}P_{S(\text { pop) }}(\mathrm{SE}) \\
\left(\mathrm{g} \text { AFDW } \mathrm{yr}^{-1} \mathrm{~m}^{-2} \text { ) }\right.\end{array}$ & $\begin{array}{c}P_{g \text { (pop) }}(\mathrm{SE}) \\
\left(\mathrm{g} \text { AFDW } \mathrm{yr}^{-1} \mathrm{~m}^{-2} \text { ) }\right.\end{array}$ & $\begin{array}{l}\text { Seafloor area } \\
\left(\mathrm{m}^{2}\right) \text { of } 10 \mathrm{~m} \\
\text { depth intervals }\end{array}$ & $\begin{array}{c}P_{S(\text { tot) }} \\
\left(\mathrm{g} \text { AFDW } \mathrm{yr}^{-1} \text { ) }\right.\end{array}$ & $\begin{array}{c}P_{g \text { (tot) }} \\
\text { (g AFDW } \mathrm{yr}^{-1} \text { ) }\end{array}$ \\
\hline 10 & $0.09(0.016)$ & $0.07(0.012)$ & $0.01(0.001)$ & $0.01(0.002)$ & 3398750 & 21328 & 43188 \\
\hline 20 & $2.53(0.015)$ & $1.86(0.110)$ & $0.18(0.011)$ & $0.36(0.020)$ & 3183750 & 569795 & 1153803 \\
\hline 30 & $3.12(0.101)$ & $2.28(0.074)$ & $0.22(0.007)$ & $0.45(0.014)$ & 3624375 & 797561 & 1615018 \\
\hline 40 & $1.19(0.064)$ & $0.87(0.047)$ & $0.08(0.005)$ & $0.17(0.009)$ & 3751250 & 315084 & 638028 \\
\hline 50 & $0.49(0.056)$ & $0.36(0.041)$ & $0.03(0.004)$ & $0.07(0.008)$ & 4203750 & 146067 & 295777 \\
\hline 60 & $0.59(0.035)$ & $0.44(0.026)$ & $0.04(0.002)$ & $0.08(0.005)$ & 5326250 & 223401 & 452374 \\
\hline Basalt $\varnothing 0-30 \mathrm{~m}$ & $8.44(0.180)$ & $6.18(0.132)$ & $0.60(0.013)$ & $1.21(0.026)$ & 621343 & 370051 & 749333 \\
\hline Sum & & & & & 24109467 & 2443287 & 4947521 \\
\hline
\end{tabular}


$0.307 \mathrm{~g} \mathrm{AFDW} \mathrm{m}^{-2} \mathrm{yr}^{-1}$ at water depths of 5 to $65 \mathrm{~m}$ in outer Young Sound, resulting in a production-to-biomass ratio of $0.29 \mathrm{yr}^{-1}$. Taking the uncertainty of the gonad production into account, this production estimate lies within the range of 0.197 and $0.420 \mathrm{~g}$ AFDW $\mathrm{m}^{-2} \mathrm{yr}^{-1}$.

Total somatic and gonad production of $S$. droe-

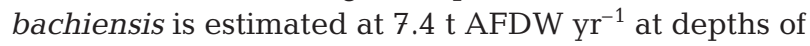
5 to $65 \mathrm{~m}$, which corresponds to approximately $1 / 3$ of the total area of Region 1 ( $\left.76 \mathrm{~km}^{2}\right)$.

The average organic carbon contents of somatic and gonad tissue were measured at $0.52 \times \mathrm{AFDW}(\mathrm{n}=11$, $\mathrm{SE}=0.0064)$ and $0.50 \times \mathrm{AFDW}(\mathrm{n}=11, \mathrm{SE}=0.0037)$, respectively.

\section{Growth patterns from high- to sub-Arctic regions}

Diameter-age plots for the 7 Greenland populations are illustrated in Fig. 6. The initial growth model involved 6 parameter values for each group, maximising the joint likelihood. It was initially clear that $a$ and $b$ in the error term $\varepsilon_{t}$ (Eq. 5) could be fitted by the same values to all groups, indicating that the error distribution was not statistically significantly different between populations $\left(a=0.489, b=0.603, \chi^{2}=14.63, \mathrm{df}=12, \mathrm{p}=\right.$ 0.26 , AIC $3185.9 \rightarrow 3176.6$ ). Focusing on the asymptotic diameter, diameter at zero age, and the shape factor $m$, we aimed to reduce this version of the model. The asymptotic diameter, $D_{\infty}$ could be constrained to be the same for all groups, and the model fit was improved $\left(\chi^{2}=1.709, \mathrm{df}=6, \mathrm{p}=0.94 ;\right.$ AIC $3176.6 \rightarrow$ 3166.3). Diameter at zero age, $D_{0}$ appeared to be poorly defined for at least some of the groups, so this parameter was also constrained equal for all groups, with minimal effect on the model $\left(\chi^{2}=13.48, \mathrm{df}=6, \mathrm{p}=\right.$ 0.04; AIC $3166.3 \rightarrow 3167.8)$. Reducing the model by constraining the shape parameter, $m$, to be uniform changed the model statistically significantly $\left(\chi^{2}=\right.$ 41.77, $\mathrm{df}=6, \mathrm{p}<0.0001$; AIC $3167.8 \rightarrow 3197.5)$, and this action was rejected. The resulting growth model parameters are listed in Table 5. There are some clear-cut differences in the growth patterns between populations (Fig. 7), which can be attributed to 2 parameters, $m$ and $T$, which are well defined in all cases. All except Qaanaaq follow a pronounced sigmoid growth pattern (i.e. $m>1$ ). The Young Sound and Qaanaaq populations are the slowest growing, while Sites 1 and 3 off Nuuk have relatively high growth rates. Growth rates

Fig. 6. Strongylocentrotus droebachiensis. Diameter vs. age plots for 7 populations from Greenland (northernmost populations top)

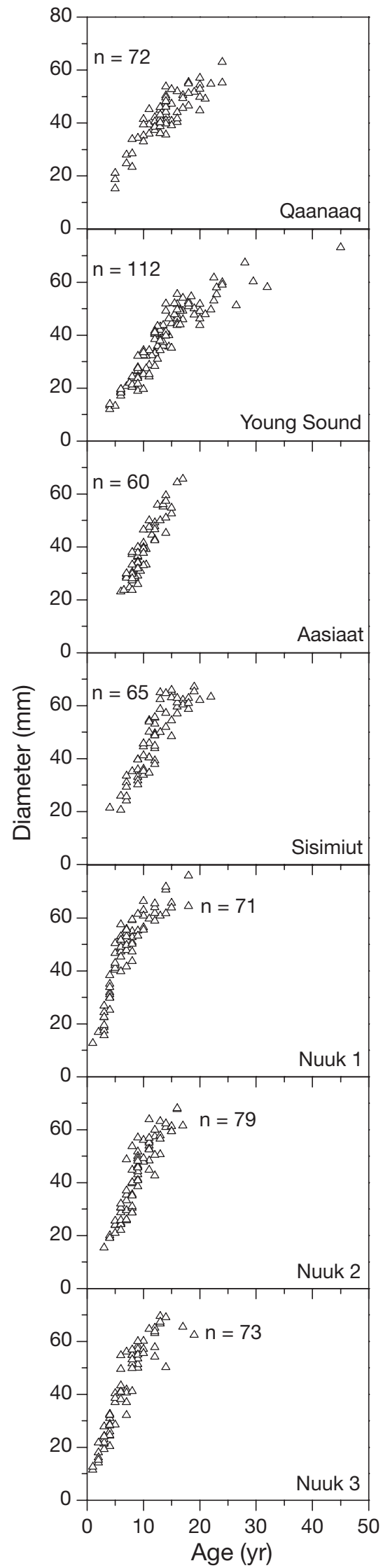


of Nuuk Site 2, Sisimiut and Aasiaat are intermediate compared with these 2 groups (Nuuk Site 2 being the faster growing) and still show fairly distinct differences between these 3 populations.

The diameter-mass relationships for the 7 groups are well defined and similar (Table 5). However, there seems to be some indication of differences between the groups. Young Sound individuals have the lowest weight for their size, followed by Aasiaat and Nuuk Site 2 . The remaining 4 groups are very similar.

\section{DISCUSSION}

\section{Young Sound}

\section{Population production}

Annual production, production-to-biomass ratios (P:B) and the fraction of production allocated to reproduction in Strongylocentrotus droebachiensis at depths of 5 to $65 \mathrm{~m}$ in outer Young Sound are compared with estimates for sea urchin populations from polar, temperate and sub-tropical areas at different depths in Table 6. Both the absolute amount of production and P:B ratios of polar species appear to be in a comparably low range and characterised by a large proportion of production being

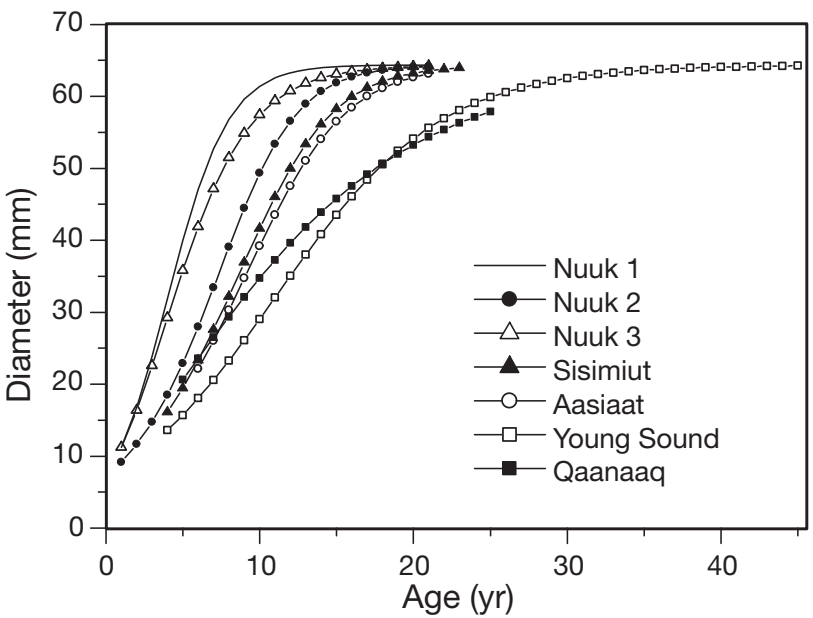

Fig. 7. Strongylocentrotus droebachiensis. Growth curves (Eq. 3) fitted to diameter-at-age data from 7 localities in Greenland. See Table 5 for parameter values

channelled into reproduction. This is markedly different from the low $P_{g}: P_{s+g}$ of the temperate $S$. droebachiensis population off Nova Scotia, Canada (Table 6) and other sea urchins from warmer climates, which never exceed $35 \%$ (Moore \& Lopez 1966, Lane 1977, Greenwood 1980). The tendency towards high reproductive effort in polar areas indicates a shift in allocation of resources

Table 5. Strongylocentrotus droebachiensis. Growth model parameters (Eq. 3) with SEs and diameter-mass relationships for 7 populations in Greenland. $D_{\infty}$ : asymptotic diameter $(\mathrm{mm}) ; D_{0}$ : estimated diameter at Age zero; $t_{*}$ : age-at-growth inflexion; $T$ (yr): time required to grow from zero to $D_{\infty}$ at maximum growth rate; $m$ : shape factor for Richards' curves. a and b are coefficients in the non-linear regression

\begin{tabular}{|c|c|c|c|c|c|c|}
\hline \multirow{2}{*}{ Locality } & \multirow[b]{2}{*}{$D_{\infty}(\mathrm{SE})$} & \multirow[b]{2}{*}{$D_{0}(\mathrm{SE})$} & \multirow{2}{*}{$\begin{array}{l}\text { Parameters } \\
m(\mathrm{SE})\end{array}$} & \multirow[b]{2}{*}{$T(\mathrm{SE})$} & \multirow[b]{2}{*}{$t *(\mathrm{SE})$} & \multirow{2}{*}{$\begin{array}{l}\text { Diameter-somatic mass relationship } \\
\text { AFDW }=a \times D_{t}^{\mathrm{b}}\end{array}$} \\
\hline & & & & & & \\
\hline Young Sound & $64.35(1.35)$ & $7.19(0.79)$ & $1.98(0.38)$ & $21.42(1.09)$ & $10.99(0.77)$ & $=4.75 \times 10^{-5} \times D_{t}^{2.52}\left(\mathrm{n}=33 ; \mathrm{R}^{2}=0.99\right)$ \\
\hline Qaanaaq & & & $0.83(0,28)$ & $21.78(0.81)$ & $5.32(1.51)$ & $=6.00 \times 10^{-5} \times D_{t}^{2.55}\left(\mathrm{n}=28 ; \mathrm{R}^{2}=0.87\right)$ \\
\hline Aasiaat & & & $2.62(0.55)$ & $14.32(0.99)$ & $9.18(0.57)$ & $=1.64 \times 10^{-5} \times D_{t}^{2.85}\left(\mathrm{n}=32 ; \mathrm{R}^{2}=0.97\right)$ \\
\hline Sisimiut & & & $2.67(0,61)$ & $13.49(0.88)$ & $8.75(0.64)$ & $=5.37 \times 10^{-5} \times D_{t}^{2.61}\left(\mathrm{n}=30 ; \mathrm{R}^{2}=0.94\right)$ \\
\hline Nuuk 1 & & & $1.97(0.42)$ & $7.82(0.50)$ & $4.01(0.67)$ & $=6.27 \times 10^{-5} \times D_{t}^{2.57}\left(\mathrm{n}=33 ; \mathrm{R}^{2}=0.98\right)$ \\
\hline Nuuk 2 & & & $2.68(0.55)$ & $11.39(0.70)$ & $7.42(0.44)$ & $=4.18 \times 10^{-5} \times D_{t}^{2.62}\left(\mathrm{n}=28 ; \mathrm{R}^{2}=0.98\right)$ \\
\hline Nuuk 3 & & & $1.49(0.31)$ & $9.57(0.46)$ & $3.90(0.42)$ & $=17.11 \times 10^{-5} \times D_{t}^{2.32}\left(\mathrm{n}=30 ; \mathrm{R}^{2}=0.98\right)$ \\
\hline
\end{tabular}

Table 6. Comparison of somatic $\left(P_{\mathrm{s}}\right)$ and gonad $\left(P_{g}\right)$ production and productivity $(P: B)$ of different sea urchin populations. In Young Sound $P_{s+g}=$ sum of $P_{s \text { (tot) }}$ and $P_{g \text { (tot) }}$ divided by total sea floor area at investigated depth interval (Table 4)

\begin{tabular}{|llccccc|}
\hline Species & Locality & Depth (m) & $\begin{array}{c}P_{s+g} \\
\text { (g AFDW m } \mathrm{yr}^{-1} \text { ) }\end{array}$ & $P_{s+g}: B_{s+g}$ & $P_{g}: P_{s+g}$ & Source \\
\hline Strongylocentrotus droebachiensis & NE Greenland & $5-65$ & 0.307 & 0.29 & 0.67 & This study \\
Strongylocentrotus pallidus & Svalbard, Norway & $150-300$ & 0.076 & 0.07 & - & Bluhm et al. (1998) \\
Sterechinus neumayeri & Antarctic & $6-25$ & $0.65-2.40$ & 0.44 & $>0.95$ & Brey et al. (1995) \\
Sterechinus antarcticus & Antarctic & $100-1200$ & $0.55 \times 10^{-3}$ & 0.116 & 0.48 & Brey (1991) \\
Strongylocentrotus droebachiensis & Nova Scotia, Canada & Subtidal & 8.44 & 0.80 & 0.19 & Miller \& Mann (1973) \\
Mellita quienquiesperforata & Florida, US & - & - & - & 0.34 & Lane (1977) \\
Moira atropes & Florida, US & - & - & - & 0.30 & Moore \& Lopez (1966) \\
Parechinus angulosus & South Africa & - & - & - & 0.18 & Greenwood (1980) \\
\hline
\end{tabular}


from somatic growth to reproduction. Thompson (1982) observed this process for $S$. droebachiensis in response to low food supply. The pattern might also be related to life in polar environments, where successful recruitment can be rather sporadic (e.g. Brey et al. 1995), as suggested by the low proportion of sea urchins $<20 \mathrm{~mm}$ diameter in the investigated areas in Young Sound (Fig. 2c). S. droebachiensis produces planktonic eggs, which develop into feeding larvae within $\sim 30 \mathrm{~d}$ (Levitan 2000). Spawning of $S$. droebachiensis may be triggered by a metabolite released by phytoplankton (Starr et al. 1990). However, a match between the development of the planktotrophic larvae and the pulsed phytoplankton bloom might be of even greater importance for the success of year classes in the Arctic.

In this respect it must be noted that estimates of $\mathrm{P}: \mathrm{B}$ ratios and production estimates in general might be greatly influenced by the reproductive state of the sea urchins at the time of collection, as exemplified by the 3 scenarios of gonad production in this study (Fig. 5a), and corrected for in the estimates of Brey (1991).

In an attempt to define the role of Strongylocentrotus droebachiensis in the carbon budget of the Young Sound ecosystem, the annual uptake of carbon was estimated based on production values. Data on production-to-consumption ratios $(\mathrm{P}: \mathrm{C})$ for echinoids in general, and $S$. droebachiensis in particular, are limited. Miller \& Mann (1973) estimated growth efficiency at 0.04 to 0.13 for $S$. droebachiensis feeding on kelp. Assuming a P:C ratio of 0.1 for $S$. droebachiensis in Young Sound, the carbon demand of this species amounts to $\sim 37 \mathrm{t} \mathrm{C}\left(0.49 \mathrm{~g} \mathrm{C} \mathrm{m}^{-2}\right) \mathrm{yr}^{-1}$, which corresponds to $3.5 \%$ of the total benthic and pelagic primary production, and $2.9 \%$ of the sedimentation of organic carbon in Region 1 (Fig. 1c) (Glud et al. 2002, Rysgaard \& Sejr 2007). These values are 2 and $3 \%$, respectively, for Strongylocentrotus pallidus at 150 to $300 \mathrm{~m}$ in the Barents Sea, and thus comparable with S. droebachiensis despite differences in depth (Bluhm et al. 1998). In contrast, Sterechinus neumayeri in the Antarctic McMurdo Sound plays a significantly larger role with a carbon demand of 12 to $30 \%$ of sedimentation and benthic microalgae production (Brey et al. 1995). In comparison, pelagic copepods in Young Sound consume 10 to $12 \mathrm{~g} \mathrm{C} \mathrm{m}^{-2} \mathrm{yr}^{-1}$ (Rysgaard et al. 1999), and the annual benthic bacterial mineralisation at 36 and $60 \mathrm{~m}$ depths is estimated at 27.5 and $12.6 \mathrm{~g} \mathrm{C}$ $\mathrm{m}^{-2}$, respectively (Rysgaard et al.1998, Glud et al. 2000). The carbon demand of Strongylocentrotus droebachiensis is comparable with estimates for the dominant bivalves Hiatella arctica and Mya truncata in Young Sound (Sejr \& Christensen 2007).

These results support the concept of benthic macrofauna playing a significant role in carbon cycling in this high-Arctic fjord ecosystem. Moreover, many benthic animals, including sea urchins, may indirectly stimulate sediment mineralisation by bioturbation (e.g. Vopel et al. 2003) and fractionation of organic material through ingestion and excretion (Mamelona \& Pelletier 2005). The relatively low density of Strongylocentrotus droebachiensis in Young Sound is in sharp contrast to the high densities that have been observed locally at littoral sites off the Atlantic coast of North America, in the fjords of Svalbard (Himmelman et al. 1983, Hop et al. 2002, Gagnon et al. 2004), and off Nuuk, West Greenland (M. E. Blicher pers. obs.). At these localities $S$. droebachiensis can be expected to contribute significantly to carbon flow.

Sea urchin abundance has been associated with the presence of hard substrate (Bluhm et al. 1998, Hop et al. 2002) and habitat food level (Brey et al. 1995). The statistically significant effect of abiotic parameters on the distribution of Strongylocentrotus droebachiensis in Young Sound might be associated with the settlement pattern of this species (Pearce \& Scheibling 1991), but the effect of depth and substrate type on density could also be caused by post-settlement processes, as proposed by Rowley (1989). Juvenile mortality might be dependent on habitat complexity (substrate) and food level (depth). Sejr \& Christensen (2007) found a similar peak in bivalve density and biomass at 20 to $40 \mathrm{~m}$ depth in Young Sound, and suggested that differences in mortality and food supply were responsible. At these depths the fauna is protected from ice scouring and is still situated in or near the photic zone with favourable food conditions. However, the general absence of sea urchins in the shallowest parts of Young Sound $(<15 \mathrm{~m})$ is primarily caused by the dominance of soft bottom. The small island, Basalt $\varnothing$, is surrounded by a steep slope dominated by rocky ground from the sea surface down to a depth of at least $30 \mathrm{~m}$. It is situated in the middle of the fjord and is clearly a unique and preferred habitat of S. droebachiensis in Young Sound. The generally low amount of rocky substratum in the euphotic zone (Glud et al. 2000) combined with low food levels at increasing depths might prevent $S$. droebachiensis in Young Sound from reaching the densities reported elsewhere.

\section{Age determination}

Although the method of age determination was not validated in the present study, several authors have validated an annual rhythm of growth line formation in the skeletons of regular sea urchins from both temperate and polar waters by means of 'tag and recapture' (Brey et al. 1995, Robinson \& McIntyre 1997), Ca:Mg isotope analysis (Robinson \& McIntyre1997) and by 'full-year monitoring' (Agatsuma \& Nakata 2004). It 
has been shown experimentally that translucent zones in the skeleton of $S$. purpuratus and Strongylocentrotus fransiscanus correspond to slow growth, and periods of food deprivation result in formation of such zones (Pearse \& Pearse 1975). Moreover, Pearse et al. (1986) demonstrated that skeletal growth in S. purpuratus provided with an unlimited amount of food, is under photoperiodic control. This means that formation of translucent zones corresponds to periods with little daylight. The long winters and short summers with corresponding intensive solar radiation and confined and pulsed primary production during summer, which dominate in polar areas (e.g. Rysgaard et al. 1999), would indeed induce formation of annual growth zones in the skeleton of Arctic S. droebachiensis. The mean intestinal index for $S$. droebachiensis in Young Sound was 0.15 in August 2004 ( $\mathrm{n}=50$, SE = 0.0009 , range 0.07 to 0.27 , for an urchin diameter of 13.4 to $73.2 \mathrm{~mm}$ ), indicating relatively high food consumption, as expected during the productive summer period (Oganesyan 1998, Brockington et al. 2001).

Although there has been some discussion as to the preciseness of the growth line-based age estimates in regular sea urchins from temperate areas, including Strongylocentrotus droebachiensis, this has primarily been concerned with the difficulties in separating the most recent growth lines in the oldest skeletal plates (Ebert 1988, Russell \& Meredith 2000). This problem was successfully overcome in the present study by including younger, faster growing plates in the process of age determination. The extreme seasonality in the areas of collection might be the reason for the distinctness of the skeletal growth zones (Brey et al. 1995), which have been lacking in some other studies of sea urchins in sub- and intertidal temperate areas (Ebert 1988, Russell \& Meredith 2000). We are therefore convinced of the reliability of the age estimates in the present study.

\section{Growth patterns from high- to sub-Arctic regions}

There are clear differences in growth pattern between sea urchin populations along the climatic gradient investigated. Growth of Strongylocentrotus droebachiensis from Greenland is generally slow compared with that of sea urchins from temperate areas. Published growth parameters from other studies report nearly all age estimates of a $50 \mathrm{~mm}$ test diameter specimen as <10 yr (Miller \& Mann 1973, Munk 1992, Meidel \& Scheibling 1998b, Russell et al. 1998, Chen et al. 2003). Only the southernmost populations off Nuuk lie within this range. These differences are probably due to a multitude of environmental factors. Food availability is generally considered a primary constraint of annual growth of benthos at high latitudes (e.g. Brockington \& Clarke 2001). Strongylocentrotus spp. in the high Arctic (either S. droebachiensis or S. pallidus-not specified) have a trophic level of 2.0 to 2.2 (Hobson \& Welch 1992, Hobson et al. 2002, Tamelander et al. 2006), and are therefore considered to be reliant on fresh algae and/or detritus as primary food sources. Most sea urchins in the present study were collected below $30 \mathrm{~m}$ depth and did not have direct access to kelp, which is found at $<15 \mathrm{~m}$ and constitutes a common food source for $S$. droebachiensis at subtidal sites (e.g. Gagnon et al. 2004). It is assumed that sea urchins at the depths of investigation primarily rely on benthic microalgae, phytodetritus and other sources of organic material sedimenting through the water column. The ratio of organic to inorganic matter in the gut of the specimens collected was low. AFDW was only $33 \%$ of the dry weight $(\mathrm{n}=70, \mathrm{SE}=0.002$, for an urchin diameter of 13.4 to $73.2 \mathrm{~mm}$ ), indicating that drifting macroalgae are not a primary food source. Annual primary production at each collection site could function as a proxy for food availability for sea urchins. Sufficient data on primary production are not available for each specific locality, but Rysgaard et al. (1999) argued that annual primary production in the Arctic was generally related to the length of the productive openwater period, which was estimated from satellite imagery in the present study (see 'Materials and methods'). In high-Arctic areas this period is identical with the ice-free period, while diminishing day lengths have a pronounced effect further south where ice-free periods are longer. The scanty data on primary production in the areas of interest support the concept of a tight correlation with the ice-free period. Annual pelagic primary production is estimated at $10 \mathrm{~g} \mathrm{C} \mathrm{m}^{-2}$ in Young Sound (Rysgaard et al. 1999), at 26 to $90 \mathrm{~g} \mathrm{C}$ $\mathrm{m}^{-2}$ in the Disko Bay area (Andersen 1981, Levinsen \& Nielsen 2002), and at 110 to $160 \mathrm{~g} \mathrm{C} \mathrm{m}^{-2}$ in the fjord system off Nuuk (Smidt 1979), but the scale of interannual and spatial variability of these values is largely unknown (see Smidt 1979, Andersen 1981).

For a direct comparison of sea urchin growth performances, the expression 1/T (maximum skeletal growth rate during the life span) is useful, but only for uniform $D_{\infty}$ and $D_{0}$, as found for the populations in this study. Generally, maximum individual production rate $P_{\max }$ ( $g$ AFDW ind. $\mathrm{yr}^{-1}$ ) would be a more valid expression of growth performance (Brey 2001). Sea urchin growth and production rates show statistically significant correlation $(p<0.01)$ with the length of the productive open-water period (Fig. 8). A likely explanation is that growth performance, especially in the high-Arctic populations, is limited by food and that annual primary productivity in these areas is influenced by sea ice cover. This tendency is in accordance with the relationship 


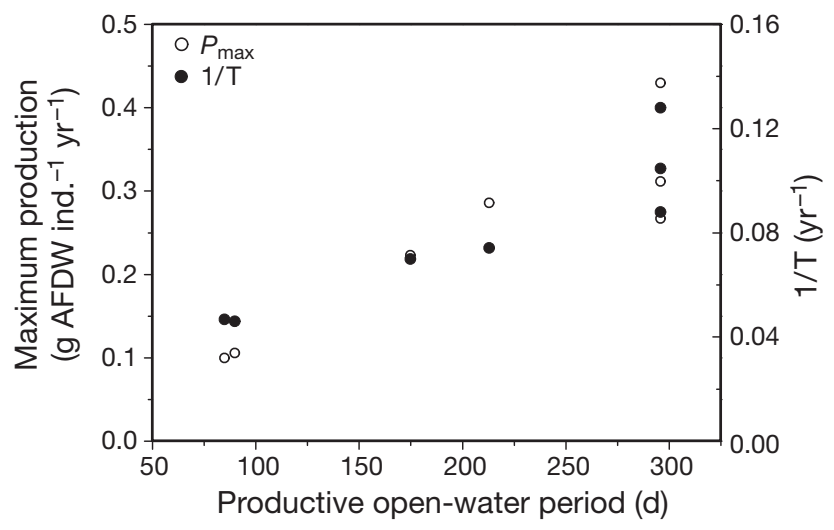

Fig. 8. Strongylocentrotus droebachiensis. Growth performance (see 'Discussion') of populations in Greenland plotted against productive open-water period (see 'Materials and methods'). Linear fits: $\mathrm{R}^{2}=0.84, \mathrm{p}=0.0039$ for $1 / T$ (maximum skeletal growth rate during life span); and $\mathrm{R}^{2}=0.81, \mathrm{p}=0.0060$ for $P_{\max }$ (maximum individual production)

between an annual index of ice cover and growth rates of the bivalve Clinocardium ciliatum collected off Greenland (M. K. Sejr \& M. E. Blicher unpubl.).

Temperature in Young Sound at 30 to $40 \mathrm{~m}$ depth is between -1.9 and $-1.0^{\circ} \mathrm{C}$ all year round (Rysgaard et al. 1999). In the Disko Bay area, temperature at the same depths ranges between $-1.8^{\circ} \mathrm{C}$ in winter and 3 to $4^{\circ} \mathrm{C}$ in September with an annual mean of $0.2^{\circ} \mathrm{C}$ at $35 \mathrm{~m}$ (Nielsen \& Hansen 1999, Sejr et al. 2007, this volume). The temperature cycle off Nuuk at the same depths displays a minimum of $\sim 0^{\circ} \mathrm{C}$ and a maximum of $\sim 4^{\circ} \mathrm{C}$ in late summer, and an annual mean of $1.5^{\circ} \mathrm{C}$ (Smidt 1979, S. Rysgaard unpubl.). If the differences in maximum production rates between individuals from Young Sound, Aasiaat and Nuuk populations are explained solely by annual mean temperature, and if the available temperature data are assumed to be representative of the areas of interest, then these differences must have been due to extremely high values of $Q_{10}$ (between 27 and 133). These unrealistic $Q_{10}$ values clearly indicate that factors other than temperature are involved. Assuming a $Q_{10}$ of 2.5 , temperature alone would account for 9 to $19 \%$ of the production rate difference between Young Sound and Nuuk populations. This is in agreement with the finding of Brockington \& Clarke (2001) that only 15 to $20 \%$ of the variation in metabolic rate of the Antarctic sea urchin Sterechinus neumayeri could be explained by temperature; 80 to $85 \%$ of the summer increase in metabolic rate was caused by the costs of feeding activity and growth. Moreover, Brockington et al. (2001) found that feeding activity of $S$. neumayeri was strongly coupled to the extremely seasonal food availability, expressed by water column chlorophyll and sediment pigment content. Activity ceased for several months under ice-covered winter conditions, indicating a dormancy period with minimal respiration as an adaptation to low food level.

Based on the above considerations, our data strongly indicate that large-scale differences in Strongylocentrotus droebachiensis growth patterns are directly coupled to food availability, as proposed for other polar species (e.g. Brey et al. 1995) and hence indirectly to the length of the productive open-water period, which is the main determinant of the level of primary production in large parts of these high latitude areas (Rysgaard et al. 1999). Other studies have recognised a relationship between latitude and growth of benthos (Heilmayer et al. 2003, 2004). On the other hand, Ebert et al. (1999) did not find a latitudinal trend in growth of $S$. franciscanus along the west coast of North America and recognised that local variation in growth rate could be as great as differences between regions; however, a relationship between growth rate and food availability was suggested. In temperate areas, primary production, and thus food availability for secondary producers, seems to be determined by a much more complex array of physical properties than in the Arctic, where primarily solar radiation limits production.

In the context of future climate change the connection between ice cover and benthos production is of highest ecological relevance. Several studies have verified an ongoing atmospheric warming, thinning of sea ice and a reduction in ice extent in Arctic areas, and climate models predict accelerated warming and corresponding changes in seasonal cycles of sea ice cover in future decades (e.g. Serreze et al. 2000, Johannesen et al. 2002, Arzel et al. 2006). Based on the results of the present study, a possible effect of decreased Arctic sea ice cover is increased annual productivity of Strongylocentrotus droebachiensis and possibly the benthic fauna in general. This effect is most pronounced in the high Arctic where the productive period is determined by sea ice cover. As sea ice cover decreases, other factors will influence annual primary production and food availability for the benthos. This is illustrated by the local variability in the Nuuk area where variations in sea urchin growth patterns are probably related to mesoscale differences in hydrographic regimes that influence primary production and benthic-pelagic coupling.

Acknowledgements. We thank M. Kingsley, Greenland Institute of Natural Resources, for his kind help with the statistical analysis of sea urchin growth patterns; L. Toudal, Technical University of Denmark, for his assistance in the analysis of sea ice; and M. M. Andreasen, University of Aarhus, for statistical advice. Uusaggak Qujaukitsoq from Qaanaaq, K. P. Mogensen from Nuuk and G. Asmund are all thanked for their assistance in sea urchin collection. Additionally, Anna Haxen is acknowledged for linguistic corrections. M.E.B. and S.R. were 
financially supported by DANCEA, the Danish Cooperation for Environment in the Arctic, Danish Ministry of Environment. M.K.S. was supported by a postdoctoral grant from Carlsberg. This work is a contribution to the Zackenberg Basic and Nuuk Basic Programmes in Greenland.

\section{LITERATURE CITED}

Agatsuma Y, Nakata A (2004) Age determination, reproduction and growth of the sea urchin Hemicentrotus pulcherrimus in Oshoro Bay, Hokkaido, Japan. J Mar Biol Assoc UK 84:401-405

Andersen OGN (1981) The annual cycle of phytoplancton primary production and hydrography in the Disko Bugt area, West Greenland. Medd Grønl Biosci 6:1-65

Arzel O, Fichefet T, Goose H (2006) Sea ice evolution over the 20th and 21st centuries as simulated by current AOGCMs. Ocean Model 12:401-415

Berry DA, Lindgren BW (1996) Statistics, theory and methods, 2nd edn. Duxbury Press, Belmont, CA

Bluhm BA, Piepenburg D, Juterzenka KV (1998) Distribution, standing stock, growth, mortality and production of Strongylocentrotus pallidus (Echinodermata: Echinoidea) in the Northern Barents Sea. Polar Biol 20:325-334

Brey T (1991) Population dynamics of Sterechinus antarcticus (Echinodermata: Echinoidea) on the Weddell Sea shelf and slope, Antarctica. Antarct Sci 3:251-256

Brey T (2001) Population dynamics in benthic invertebrates. A virtual handbook. Version 01.2. Available at: www.awi-bremerhaven.de/Benthic/Ecosystem/FoodWeb/ Handbook/main.html. Alfred Wegener Institute for Polar and Marine Research, Bremerhaven

Brey T, Pearse J, Basch L, McClintock J (1995) Growth and production of Sterechinus neumayeri (Echinoidea: Echinodermata) in McMurdo Sound, Antarctica. Mar Biol 124: 279-292

Brockington S, Clarke A (2001) The relative influence of temperature and food on the metabolism of a marine invertebrate. J Exp Mar Biol Ecol 258:87-99

Brockington S, Clarke A, Chapman ALG (2001) Seasonality of feeding and nutritional status during the austral winter in the Antarctic sea urchin Sterechinus neumayeri. Mar Biol 139:127-138

Chen Y, Hunter M, Vadas R, Beal B (2003) Developing a growth-transition matrix for the stock assessment of the green sea urchin (Strongylocentrotus droebachiensis) off Maine. Fish Bull (Wash DC) 101:737-744

Ebert TA (1988) Calibration of natural growth lines in ossicles of two sea urchins, Strongylocentrotus purpuratus and Echinometra mathaei, using tetracycline. In: Burke RD, Mladenov P, Lambert P, Parsley RL (eds) Echinoderms: Proc 6th Int Echinoderm Conf. A.A. Balkema, Rotterdam, p 435-444

Ebert TA, Russell MP (1994) Allometry and model II nonlinear regression. J Theor Biol 168:367-372

Ebert TA, Dixon JD, Schroeter SC, Kalvass PE, Richmond NT, Bradbury WA, Woodby DA (1999) Growth and mortality of red sea urchins Strongylocentrotus franciscanus across a latitudinal gradient. Mar Ecol Prog Ser 190:189-209

Gagnon P, Himmelman JH, Johnson LE (2004) Temporal variation in community interfaces: kelp boundary dynamics to persistent urchin barrens. Mar Biol 144:1191-1203

Gloerson P, Cavalieri D, Campbell WJ, Zwally J (1990) Nimbus-7 SMMR polar radiances and Arctic and Antarctic sea ice concentrations. National Snow and Ice Data Center, Boulder, CO. CD-ROM
Glud RN, Risgaard-Petersen N, Thamdrup B, Fossing H, Rysgaard S (2000) Benthic carbon mineralization in a highArctic sound (Young Sound, NE Greenland). Mar Ecol Prog Ser 206:59-71

Glud RN, Kuhl M, Wenzhöfer F, Rysgaard S (2002) Benthic diatoms of a high Arctic fjord (Young Sound, NE Greenland): importance for ecosystem primary production. Mar Ecol Prog Ser 238:15-29

Greenwood PJ (1980) Growth, respiration and tentative energy budgets for two populations of the sea urchin Parechinus angulosus (Leske). Estuar Coast Mar Sci 10:347-367 (Cited after Brey et al. 1995)

Heilmayer O, Brey T, Chiantore M, Cattaneo-Vietti R, Arntz WE (2003) Age and productivity of the Antarctic scallop, Adamussium colbecki, in Terra Nova Bay (Ross Sea, Antarctica). J Exp Mar Biol Ecol 288:239-256

Heilmayer O, Brey T, Pörtner HO (2004) Growth efficiency and temperature in scallops: a comparative analysis of species adapted to different temperatures. Funct Ecol 18: 641-647

Himmelman JH, Cardinal A, Bourget E (1983) Community development following mass mortalities of urchins, Strongylocentrotus droebachiensis, from the rocky subtidal zone of the St. Lawrence Estuary, Eastern Canada. Oecologia 59:27-39

Hobson KA, Welch HE (1992) Determination of trophic relationships within a high Arctic marine food web using $\delta^{13} \mathrm{C}$ and $\delta^{15} \mathrm{~N}$ analysis. Mar Ecol Prog Ser 84:9-18

Hobson KA, Fisk A, Karnovsky N, Holst M, Gagnon J, Fortier $M$ (2002) A stable isotope $\left(\delta^{13} C, \delta^{15} N\right)$ model for the North Water food web: implications for evaluating trophodynamics and the flow of energy and contaminants. DeepSea Res II 49:5131-5150

Hop H, Pearson TH, Hegset EN, Kovacs KM and 24 others (2002) The marine ecosystem of Kongsfjorden, Svalbard. Polar Res 21:167-208

Jensen M (1969) Age determination of Echinoids. Sarsia 37: $41-44$

Johannesen OM, Bengtson L, Miles MW, Kuzmina SI and 8 others (2002) Arctic climate change-observed and modelled temperature and sea ice variability. Tech Rep 218, Nansen Environmental and Remote Sensing Center, Bergen

Lane JM (1977) Bioenergetics of the sand dollar, Mellita quinquiesperforata (Leske, 1778). PhD thesis, University of South Florida, Miami. (Cited after Brey et al. 1995)

Lebreton JD, Burnham KP, Clobert J, Anderson D (1992) Modelling survival and testing biological hypothesis using marked animals: a unified approach with case studies. Ecol Monogr 62:67-118

Levinsen H, Nielsen TG (2002) The trophic role of marine pelagic ciliates and heterotrophic dinoflagellates in arctic and temperate coastal ecosystems: a cross-latitude comparison. Limnol Oceanogr 47:427-439

Levitan DR (2000) Optimal egg size in marine invertebrates: theory and phylogenetic analysis of the critical relationship beween egg size and development time in echinoids. Am Nat 156:175-192

Mamelona J, Pelletier É (2005) Green sea urchin as a significant source of fecal particulate organic matter within nearshore benthic ecosystems. J Exp Mar Biol Ecol 314: 163-174

Maslanik J, Stroeve J (2004) DMSP SSM/I daily polar gridded brightness temperatures, July 1977 to October 2004. National Snow and Ice Data Center, Boulder, CO. CD-ROM

Meidel SK, Scheibling RE (1998a) Annual reproductive cycle of the green sea urchin, Strongylocentrotus droebachien- 
sis, in differing habitats in Nova Scotia, Canada. Mar Biol 131:461-478

Meidel SK, Scheibling RE (1998b) Size and size structure of the sea urchin Strongylocentrotus droebachiensis in different habitats. In: Mooi R, Telford M (eds) Echinoderms: San Francisco. Balkema, Rotterdam, p 737-742

Miller RJ, Mann KH (1973) Ecological energetics of the seaweed zone in a marine bay on the Atlantic coast of Canada. III. Energy transformations by sea urchins. Mar Biol 18:99-114

Moore HB, Lopez NN (1966) The ecology and productivity of Moira atropes (L.) Bull Mar Sci 16:468-667. (Cited after Brey et al. 1995)

Munk JE (1992) Reproduction and growth of green sea urchins Strongylocentrotus droebachiensis (Müller) near Kodiak, Alaska. J Shellfish Res 11:245-254

Nielsen TG, Hansen BW (1999) Plankton community structure and carbon cycling on the western coast of Greenland during the stratified summer situation. I. Hydrography, phytoplankton and bacterioplankton. Aquat Microb Ecol 16:205-216

Oganesyan SA (1998) Reproductive cycle of the echinoid Strongylocentrotus droebachiensis in the Barents Sea. In: Mooi R, Telford M (eds) Echinoderms: San Francisco. Balkema, Rotterdam, p 765-768

Pearce CM, Scheibling RE (1991) Effect of macroalgae, microbial films, and conspecifics on the induction of metamorphosis of the green sea urchin Strongylocentrotus droebachiensis. J Exp Mar Biol Ecol 147:147-162

Pearce CM, Daggett TL, Robinson SMC (2004) Effect of urchin size and diet on gonad yield and quality in the green sea urchin (Strongylocentrotus droebachiensis). Aquaculture 233:337-367

Pearse JS, Pearse VB (1975) Growth zones in the echinoid skeleton. Am Zool 15:731-753

Pearse JS, Pearse VB, Davis KK (1986) Photoperiodic regulation of gametogenesis and growth in the sea urchin Strongylocentrotus purpuratus. J Exp Zool 237:107-118

Petersen GH, Curtis MA (1980) Differences in energy flow through major components of subarctic, temperate and tropical marine shelf ecosystems. Dana 1:53-64

Piepenburg D (2005) Recent research on Arctic benthos: common notions need to be revised. Polar Biol 28:733-755

Richards FJ (1959) A flexible growth function for empirical use. J Exp Bot 10:290-300

Robinson SMC, McIntyre AD (1997) Aging and growth of the green sea urchin. Bull Aquac Assoc Can 97:56-60

Rowley RJ (1989) Settlement and recruitment of sea urchins (Strongylocentrotus spp.) in a sea-urchin barren ground and a kelp bed: are populations regulated by settlement or post-settlement processes? Mar Biol 100:485-494

Russell MP, Meredith RW (2000) Natural growth lines in echinoid ossicles are not reliable indicators of age: a test using Strongylocentrotus droebachiensis. Invertebr Biol 119:410-420

Russell MP, Ebert TA, Petraitis PS (1998) Field estimates of growth and mortality of the green sea urchin, Strongylocentrotus droebachiensis. Ophelia 48:137-153

Editorial responsibility: Otto Kinne (Editor-in-Chief), Oldendorf/Luhe, Germany
Rysgaard S, Sejr MK (2007) Vertical flux of particulate matter in a high-arctic fjord: relative importance of terrestrial and marine sources. In: Rysgaard S, Glud RN (eds) Carbon cycling in Arctic marine ecosystems: case study Young Sound. Medd Grønl Biosci (Spec Issue):110-119

Rysgaard S, Thamdrup B, Risgaard-Petersen N, Fossing $H_{\text {, }}$ Berg P, Christensen PB, Dalsgaard T (1998) Seasonal carbon and nutrient mineralization in a high-Arctic coastal marine sediment, Young Sound, Northeast Greenland. Mar Ecol Prog Ser 175:261-275

Rysgaard S, Nielsen TG, Hansen BW (1999) Seasonal variation in nutrients, pelagic primary production and grazing in a high-arctic coastal marine ecosystem, Young Sound, Northeast Greenland. Mar Ecol Prog Ser 179:13-25

Rysgaard S, Vang T, Stjernholm M, Rasmussen B, Windelin A, Kiisholm S (2003) Physical conditions, carbon transport, and climate change impacts in a Northeast Greenland fjord. Arct Antarct Alp Res 35:301-312

Sejr MK, Christensen PB (2007) Growth, production and carbon demand of macrofauna in Young Sound, with special emphasis on the bivalves Hiatella arctica and Mya truncata. In: Rysgaard S, Glud RN (eds) Carbon cycling in Arctic marine ecosystems: case study Young Sound. Medd Grønl Biosci (Spec Issue):122-135

Sejr MK, Nielsen TG, Rysgaard S, Risgaard-Petersen N, Sturluson M, Blicher ME (2007) Fate of pelagic organic carbon and importance of the benthic-pelagic coupling in a shallow cove in Disko Bay, West Greenland. Mar Ecol Prog Ser 341:75-88

Serreze MC, Walsh JE, Chapin FS III, Osterkamp T and 6 others (2000) Observational evidence of recent change in the northern high-latitude environment. Clim Change 46: 159-207

Smidt EBL (1979) Annual cycles of primary production and of zooplankton at Southwest Greenland. Greenl Biosci $1: 1-53$

Starr M, Himmelman JH, Therriault JC (1990) Direct coupling of marine invertebrate spawning with phytoplankton blooms. Science 247:1071-1074

Sugden LG, Driver EA, Kingsley MCS (1981) Growth and energy consumption by captive mallards. Can J Zool 59: 1567-1570

Tamelander T, Renaud PE, Hop H, Carroll ML, Ambrose WG Jr, Hobson KA (2006) Trophic relationships and pelagic-benthic coupling during summer in the Barents Sea marginal ice zone, revelaed by stable carbon and nitrogen isotope measurements. Mar Ecol Prog Ser 310:33-46

Thompson RJ (1982) The relationship between food ration and reproductive effort in the green sea urchin Strongylocentrotus droebachiensis. Oecologia 56:50-57

Thorson G (1936) The larval development, growth, and metabolism of arctic marine bottom invertebrates compared with those of other seas. Medd Grønl 100:1-155

Vopel K, Thistle D, Rosenberg R (2003) Effect of the brittle star Amphiura filiformis (Amphiuridae, Echinodermata) on oxygen flux into the sediment. Limnol Oceanogr 48: 2034-2045

Submitted: March 31, 2006; Accepted: December 8, 2006 Proofs received from author(s): June 18, 2007 